\title{
Deinococcus daejeonensis sp. nov., isolated from sludge in a sewage disposal plant
}

\author{
Sathiyaraj Srinivasan, ${ }^{1,2}$ Myung Kyum Kim, ${ }^{1}$ Sangyong Lim, ${ }^{3}$ Minho Joe ${ }^{3}$ \\ and Myungjin Lee ${ }^{2}$
}

Correspondence
Myungjin Lee
mgeneli@nate.com

\author{
${ }^{1}$ Department of Bio \& Environmental Technology, Division of Environmental \& Life Science, \\ College of Natural Science, Seoul Women's University, 623 Hwarangno, Nowon-gu, \\ Seoul 139-774, Republic of Korea \\ ${ }^{2}$ Research and Development Division, H-Plus Eco Ltd, BVC \#301, KRIBB, Eoeun-dong, \\ Yuseong-gu, Daejeon 305-333, Republic of Korea \\ ${ }^{3}$ Radiation Research Division for Biotechnology, Korea Atomic Energy Research Institute, \\ Jeongeup 580-185, Republic of Korea
}

A Gram-stain-positive, strictly aerobic, spherical, non-motile red-pigmented bacterial strain, designated $\mathrm{MJ} 27^{\top}$, was isolated from a sludge sample of the Daejeon sewage disposal plant in South Korea. A polyphasic approach was used to study the taxonomic position of strain $\mathrm{MJ}_{27}{ }^{\top}$. Strain MJ27 ${ }^{\top}$ shared highest $16 \mathrm{~S}$ rRNA gene sequence similarity with Deinococcus grandis DSM $3963^{\top}(98.8 \%)$, Deinococcus caeni Ho-08 ${ }^{\top}(97.5 \%)$ and Deinococcus aquaticus PB314 ${ }^{\top}$ (96.6\%.); levels of sequence similarity with the type strains of other Deinococcus species were less than $96.0 \%$. Phylogenetic analysis based on 16S rRNA gene sequences showed that strain $\mathrm{MJ} 27^{\top}$ belonged to the clade formed by members of the genus Deinococcus in the family Deinococcaceae. The $G+C$ content of the genomic DNA of strain MJ27 ${ }^{\top}$ was $67.6 \mathrm{~mol} \%$. The chemotaxonomic characteristics of strain $M J 27^{\top}$ were typical of members of the genus Deinococcus, with MK-8 as the predominant respiratory quinone, $\mathrm{C}_{16: 1} \omega 7 c, \mathrm{C}_{15: 1} \omega 6 c, \mathrm{C}_{16: 0}$ and $\mathrm{C}_{15: 0}$ as major fatty acids $(>12 \%)$, ornithine as the diamino acid in the cell-wall peptidoglycan and resistance to gamma radiation $\left[D_{10}\right.$ (dose required to reduce the bacterial population by tenfold) $>9 \mathrm{kGy}$. The low levels of DNA-DNA relatedness reported here $(5.3 \pm 1.5-29.2 \pm 2.3 \%)$ indicate that strain $M J 27^{\top}$ represents a species that is separate from its closest relatives in the genus Deinococcus. On the basis of phylogenetic inference, fatty acid profile and other phenotypic properties, strain $\mathrm{MJ} 27^{\top}$ is considered to represent a novel species of the genus Deinococcus, for which the name Deinococcus daejeonensis sp. nov. is proposed. The type strain is $\mathrm{MJ}_{27} 7^{\top}\left(=\mathrm{KCTC} 13751^{\top}=\mathrm{JCM} 16918^{\top}\right)$.
Concerns about cell damage caused by X-ray irradiation in hospitals or radioactive material emitted from nuclear power stations have led to studies on the effect of radiation on the human body (Kwon \& Seo, 2010; Seong et al., 2010). The mechanisms by which damaged cells recover from radiation are a major issue, so radiationresistant bacteria are becoming increasingly important as sources of radiation-resistant enzymes and other molecules. The genus Deinococcus is notable for its radiation resistance and is a good model for recovery of particular biomolecules.

\footnotetext{
The GenBank/EMBL/DDBJ accession number for the $16 \mathrm{~S}$ rRNA gene sequence of strain $\mathrm{MJ}^{2} 7^{\top}$ is JF806527.

One supplementary figure is available with the online version of this paper.
}

The genus Deinococcus was proposed by Brooks \& Murray (1981) and, at the time of writing, comprised more than 45 recognized species. Species of the genus Deinococcus are aerobic and show high resistance to ionizing radiation, colony colour ranges from yellow to pink, orange and red, they are commonly Gram-stain-positive (some strains are Gram-stain-negative), they have L-ornithine in the cell-wall peptidoglycan and they lack teichoic acids.

During the course of collecting micro-organisms from sludge at the Daejeon sewage disposal plant, South Korea, a Gramstain-positive, non-motile, aerobic, non-spore-forming strain, MJ27 ${ }^{\mathrm{T}}$, was isolated. On the basis of $16 \mathrm{~S}$ rRNA gene sequence analysis, strain $\mathrm{MJ} 27^{\mathrm{T}}$ was considered to belong to the genus Deinococcus. Strain $\mathrm{MJ} 27^{\mathrm{T}}$ was subjected to a polyphasic taxonomic investigation and the results indicated that it represents a novel species of the genus Deinococcus. 


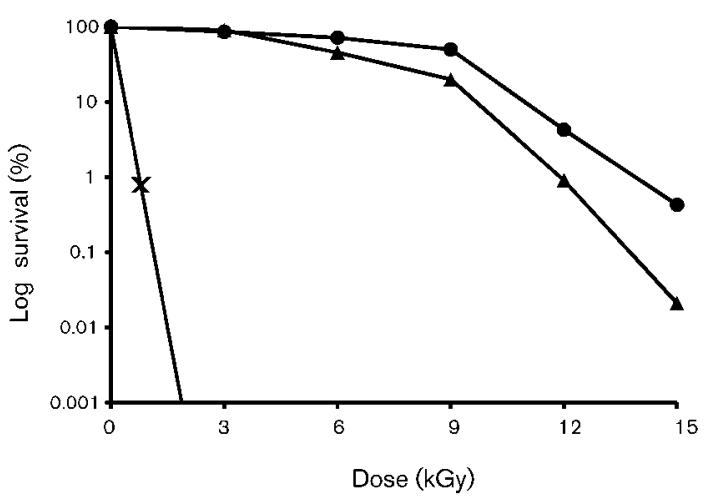

Fig. 1. Representative survival plot for strain $M J 27^{\top}(\mathbf{\Delta})$ following exposure to gamma radiation. Survival rates of $D$. radiodurans $\mathrm{R} 1$ (O) and $E$. coli $(x)$ are also shown. Each increment on the $y$-axis represents a tenfold reduction in viability.

For isolation of strain $\mathrm{MJ} 27^{\mathrm{T}}, 1 \mathrm{~g}$ soil sample was mixed with $50 \mathrm{ml}$ saline $(0.85 \% \mathrm{NaCl})$, vortexed, serially diluted and $100 \mu \mathrm{l}$ of each dilution was spread onto $0.1 \times \mathrm{R} 2 \mathrm{~A}$ agar (Difco) and incubated at $30{ }^{\circ} \mathrm{C}$ for 1 week. Single colonies were transferred onto new plates and the purified colonies were tentatively identified by analysis of partial $16 \mathrm{~S}$ rRNA gene sequences. Isolate $\mathrm{MJ} 27^{\mathrm{T}}$ was routinely cultured on nutrient agar (NA; Difco) at $30{ }^{\circ} \mathrm{C}$ and preserved as a suspension in Luria-Bertani (LB; Difco) broth with $20 \%$ glycerol $(\mathrm{w} / \mathrm{v})$ at $-70{ }^{\circ} \mathrm{C}$.

To determine the survival rate after exposure to gamma radiation, cultures were grown at $30{ }^{\circ} \mathrm{C}$ in liquid nutrientrich TGY medium ( $1 \%$ tryptone, $0.1 \%$ glucose, $0.5 \%$ yeast extract) or on TGY solid medium (TGY medium plus $1.5 \%$ agar). To measure ionizing radiation resistance, cultures grown to the early stationary phase $\left(\sim 10^{9}\right.$ cells $\left.\mathrm{ml}^{-1}\right)$ were divided into $1 \mathrm{ml}$ aliquots without change of broth and were exposed on ice to a cobalt-60 gamma irradiator (point source; AECL, IR-79). The source strength was approximately $100 \mathrm{kCi}(3.7 \mathrm{GBq})$ at a dose rate of $70 \mathrm{~Gy} \min ^{-1}$; actual doses were within $2 \%$ of the target dose. Irradiated cells were diluted, plated in triplicate on TGY agar plates and incubated for 2 days before survival rates were scored. Deinococcus radiodurans R1 and Escherichia coli cells were used as positive and negative control strains for the experiment. Strain $\mathrm{MJ} 27^{\mathrm{T}}$ showed good resistance to $3 \mathrm{kGy}$ gamma radiation $\left(90 \%\right.$ survival for $D$. radiodurans and $\left.\mathrm{MJ} 27^{\mathrm{T}}\right)$; at $9 \mathrm{kGy}$, strain $\mathrm{MJ} 27^{\mathrm{T}}$ showed $20 \%$ survival compared with $50 \%$ for D. radiodurans R1 (Fig. 1). Radiation resistance is one of the main characteristics of members of the genus Deinococcus. Most radiation-resistant Deinococcus species were isolated by selection using UV or gamma radiation (Rainey et al., 2005; Oyaizu et al., 1987); however, strain MJ2 $27^{\mathrm{T}}$ was isolated without any radiation selection method, but showed resistance to gamma radiation.

The genomic DNA of strain MJ $27^{\mathrm{T}}$ was extracted by using a commercial genomic DNA extraction kit (Solgent);
PCR-mediated amplification of the 16S rRNA gene and sequencing of the purified PCR product were carried out according to Kim et al. (2005). The nearly complete sequence of the 16S rRNA gene (1464 nt) was compiled with SeqMan software (DNASTAR). The 16S rRNA gene sequences of related taxa were obtained from GenBank and were edited by using the program BioEdit (Hall, 1999). Multiple alignments were performed with the program CLUSTAL X (Thompson et al., 1997). Evolutionary distances were calculated with the Kimura two-parameter model (Kimura, 1983). Phylogenetic trees were constructed by using the neighbour-joining (Saitou \& Nei, 1987) and maximum-parsimony (Fitch, 1971) methods in MEGA3 (Kumar et al., 2004) with bootstrap values based on 1000 replications (Felsenstein, 1985). In the neighbour-joining tree based on 16S rRNA gene sequences, strain MJ27 belonged to the clade formed by members of the genus Deinococcus in the family Deinococcaceae (Fig. 2).

On the basis of levels of $16 \mathrm{~S}$ rRNA gene sequence similarity, the closest relatives of strain $\mathrm{MJ} 27^{\mathrm{T}}$ were Deinococcus grandis DSM $3963^{\mathrm{T}}(98.8 \%)$, Deinococcus caeni $\mathrm{Ho}-08^{\mathrm{T}}(97.5 \%)$, Deinococcus aquaticus PB314 ${ }^{\mathrm{T}}(96.6 \%)$ and Deinococcus indicus $\mathrm{Wt} / 1 \mathrm{a}^{\mathrm{T}}(95.6 \%)$. Levels of sequence similarity to other Deinococcus species were $\leqslant 95 \%$. Consequently, the above type strains of Deinococcus species were obtained and grown under the same conditions as for strain $\mathrm{MJ} 27^{\mathrm{T}}$ and used as reference strains for phenotypic and chemotaxonomic experiments.

Cell morphology and motility were observed with an Olympus light microscope $(1000 \times$ magnification), by using cells grown for $24 \mathrm{~h}$ in nutrient broth at $30^{\circ} \mathrm{C}$. For electron microscopy, cells were gently resuspended in one drop of deionized $\mathrm{H}_{2} \mathrm{O}$ and samples were placed on carbon- and Formvar-coated nickel grids for $30 \mathrm{~s}$. Grids were floated on one drop of $0.1 \%(\mathrm{w} / \mathrm{v})$ aqueous uranyl acetate, blotted dry and then viewed with a Carl Zeiss LEO912AB electron microscope at $100 \mathrm{kV}$ under standard operating conditions. The Gram reaction was performed by using the non-staining method, as described by Buck (1982). Catalase activity was assessed by bubble production in $3 \%(\mathrm{v} / \mathrm{v}) \mathrm{H}_{2} \mathrm{O}_{2}$ and oxidase activity was assessed by using $1 \%(\mathrm{w} / \mathrm{v})$ tetramethyl $p$-phenylenediamine (Cappuccino \& Sherman, 2002). Anaerobic growth was examined in serum bottles with sodium thioglycolate $\left(1 \mathrm{~g} \mathrm{l}^{-1}\right)$ added to nutrient broth and the upper air layer was replaced with nitrogen. Physiological characteristics were determined with API 20NE, API ID $32 \mathrm{GN}$ and API ZYM galleries (bioMérieux) according to the manufacturer's instructions. Growth at $4,10,20,25,28,30,37,40,42$ and $45{ }^{\circ} \mathrm{C}$ and at $\mathrm{pH} 3.0-12.0$ (0.5 pH unit intervals) was assessed in LB broth for 5 days. The $\mathrm{pH}$ of the medium was adjusted by using diluted $\mathrm{NaOH}$ and $\mathrm{HCl}$. Salt tolerance was tested in R2A broth supplemented with $0-10 \%(\mathrm{w} / \mathrm{v}) \mathrm{NaCl}$ incubated for 5 days at $30{ }^{\circ} \mathrm{C}$. Growth on trypticase soy agar (TSA; Difco), $\mathrm{R} 2 \mathrm{~A}$ agar and LB agar was also evaluated at $30^{\circ} \mathrm{C}$. The phenotypic characteristics of strain $\mathrm{MJ} 27^{\mathrm{T}}$ are given in the species description below and those that differentiated strain 


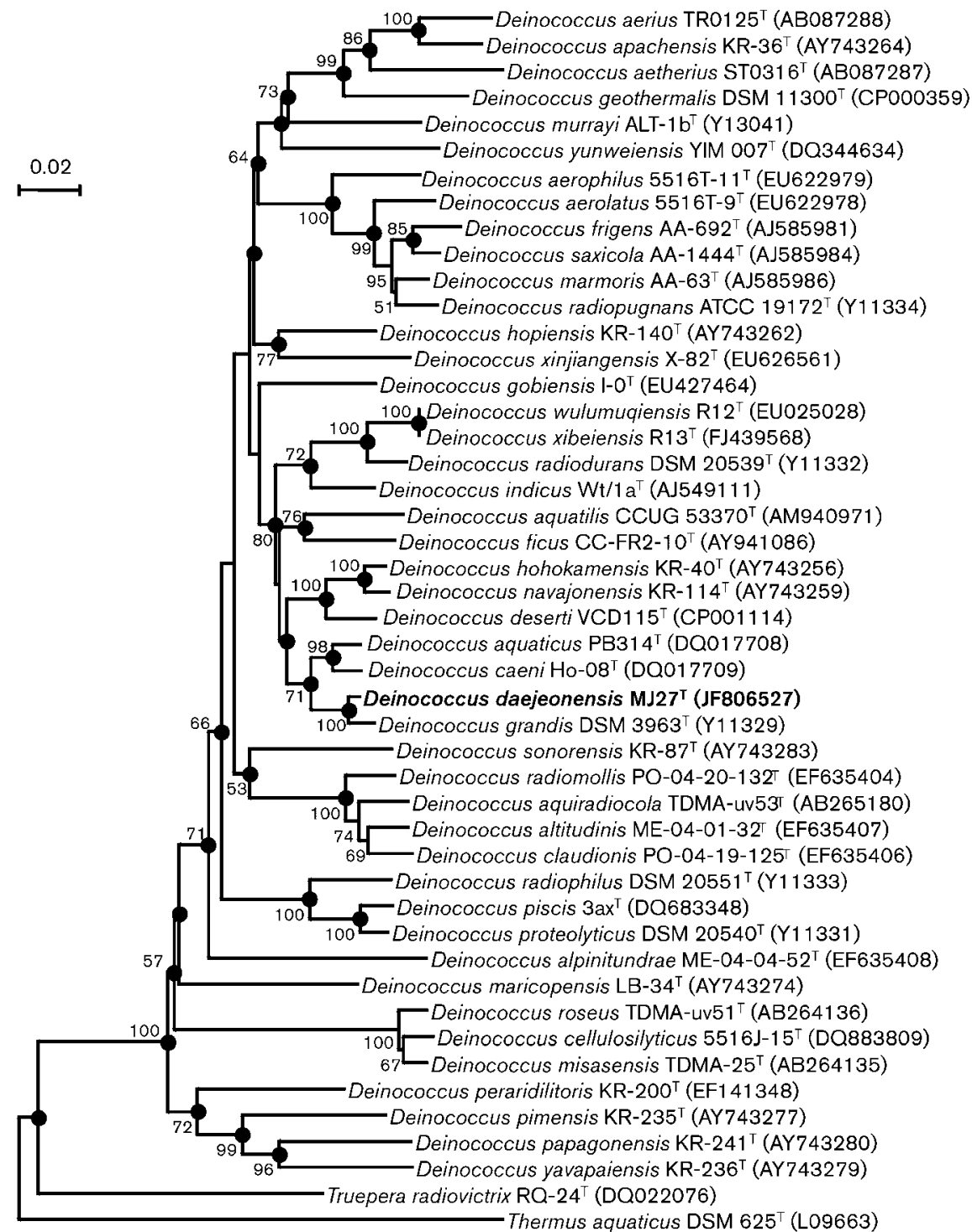

Fig. 2. Neighbour-joining phylogenetic tree based on 16S rRNA gene sequences showing the relationships between strain $\mathrm{MJ} 27^{\top}$ and the type strains of recognized Deinococcus species. Numbers at branch points are bootstrap values (percentages of 1000 replications); only values $>50 \%$ are shown. Filled circles indicate that the corresponding nodes were also recovered in the tree generated with the maximum-parsimony algorithm. The sequence from Thermus aquaticus DSM $625^{\top}$ was used as an outgroup. Bar, 0.02 substitutions per nucleotide position.

MJ $27^{\mathrm{T}}$ from the type strains of closely related species are given in Table 1.

Isoprenoid quinones were extracted from bacterial cells of strain MJ $27^{\mathrm{T}}$ with chloroform/methanol $(2: 1, \mathrm{v} / \mathrm{v})$, evaporated under vacuum and re-extracted in $n$-hexane/water $(1: 1, \mathrm{v} / \mathrm{v})$. The crude $\mathrm{n}$-hexane/quinone solution was then purified by using silica Sep-Pak Vac cartridges (Waters) and was subsequently analysed by HPLC, as described by Hiraishi et al. (1996). Strain MJ $27^{\mathrm{T}}$ contained menaquinone MK- 8 as the major respiratory quinone. The peptidoglycan was analysed as described by Schleifer \& Kandler (1972) by using TLC on cellulose sheets instead of paper chromatography. Strain MJ $27^{\mathrm{T}}$ had ornithine and glycine as major amino acids in the peptidoglycan structure, in line with data for members of the genus Deinococcus. Cell-wall sugars contained rhamnose and ribose, as commonly observed in Deinococcus species.

For fatty acid methyl ester analysis, strain $M J 27^{\mathrm{T}}$ was grown on TSA and harvested at the early stationary growth phase at $30{ }^{\circ} \mathrm{C}$. Two loopfuls of bacterial mass were collected and subjected to saponification, methylation and extraction according to the methods of Kuykendall et al. (1988). The fatty acid methyl ester mixtures were separated by using the Sherlock Microbial Identification System 
Table 1. Differential characteristics of strain $M J 27^{\top}$ and the type strains of closely related Deinococcus species

Strains: $1, \mathrm{MJ} 27^{\mathrm{T}}$; 2, D. aquaticus KCTC $12552^{\mathrm{T}}$; 3, D. caeni KCTC $12553^{\mathrm{T}}$; 4, D. grandis KACC $11979^{\mathrm{T}}$; 5, D. radiodurans KACC $12248^{\mathrm{T}}$. All data are from this study and were determined under the same experimental conditions. All strains are non-motile and do not produce acid from glucose. W, Weakly positive reaction.

\begin{tabular}{|c|c|c|c|c|c|}
\hline Characteristic & 1 & 2 & 3 & 4 & 5 \\
\hline Gram staining & + & - & - & - & + \\
\hline Morphology & Coccus & Rod & Rod & Rod & Coccus \\
\hline Colony colour & Red & Red & Pink & Pink & Red \\
\hline \multicolumn{6}{|l|}{ Growth at/with (LB): } \\
\hline $15{ }^{\circ} \mathrm{C}$ & + & - & - & - & + \\
\hline $42{ }^{\circ} \mathrm{C}$ & - & - & - & + & + \\
\hline $\mathrm{pH} 6$ & + & - & - & - & + \\
\hline pH 8.5 & + & + & + & - & - \\
\hline $2 \% \mathrm{NaCl}$ & + & + & + & - & + \\
\hline $4 \% \mathrm{NaCl}$ & + & - & - & - & + \\
\hline Nitrate reduction & - & - & - & + & - \\
\hline \multicolumn{6}{|l|}{ Enzyme activity } \\
\hline Oxidase & - & + & - & - & + \\
\hline Alkaline phosphatase & + & + & + & + & + \\
\hline Arginine dihydrolase & + & - & - & - & - \\
\hline$\alpha$-Chymotrypsin & + & + & - & - & + \\
\hline Esterase (C4) & + & + & $\mathrm{w}$ & + & $\mathrm{w}$ \\
\hline$\beta$-Galactosidase (ONPG) & + & + & $\mathrm{w}$ & + & $\mathrm{w}$ \\
\hline$\beta$-Glucosidase & + & + & - & + & - \\
\hline $\begin{array}{l}\text { Naphthol-AS-BI- } \\
\text { phosphohydrolase }\end{array}$ & + & + & + & + & - \\
\hline Valine arylamidase & + & $\mathrm{w}$ & $\mathrm{w}$ & - & - \\
\hline Gelatin hydrolysis & + & - & - & - & + \\
\hline Starch hydrolysis & + & + & + & + & $\mathrm{w}$ \\
\hline \multicolumn{6}{|l|}{ Assimilation of: } \\
\hline 3-Hydroxybenzoate & $\mathrm{w}$ & $\mathrm{w}$ & - & $\mathrm{w}$ & + \\
\hline 4-Hydroxybenzoate & + & + & $\mathrm{w}$ & + & + \\
\hline 2-Ketogluconate $(\alpha)$ & - & $\mathrm{w}$ & - & + & + \\
\hline 5-Ketogluconate & + & + & $\mathrm{w}$ & + & + \\
\hline Acetate & - & - & - & $\mathrm{w}$ & + \\
\hline Caprate & $\mathrm{w}$ & $\mathrm{w}$ & - & + & + \\
\hline Citrate & $\mathrm{W}$ & $\mathrm{w}$ & - & + & + \\
\hline DL-Lactate & + & + & - & $\mathrm{w}$ & + \\
\hline Propionate & - & - & + & - & - \\
\hline L-Fucose & - & + & - & + & + \\
\hline D-Glucose & + & + & - & + & + \\
\hline Melibiose & + & $\mathrm{w}$ & - & $\mathrm{w}$ & + \\
\hline L-Rhamnose & + & $\mathrm{w}$ & + & - & + \\
\hline Sucrose & + & + & - & + & - \\
\hline myo-Inositol & + & + & - & + & + \\
\hline D-Mannitol & + & + & - & + & + \\
\hline L-Alanine & $\mathrm{w}$ & $\mathrm{w}$ & + & - & - \\
\hline L-Serine & - & + & - & + & + \\
\hline $\mathrm{N}$-Acetyl-D-glucosamine & - & + & + & - & + \\
\hline Salicin & + & + & - & $\mathrm{w}$ & - \\
\hline Glycogen & - & - & + & - & - \\
\hline DNA G $+C$ content $(\mathrm{mol} \%)$ & 67.6 & 68.3 & 68.4 & 68.4 & 67.0 \\
\hline
\end{tabular}

(TSBA, version 6.0; MIDI), analysed by GC (Hewlett Packard 6890) and identified via the Microbial Identification software package (Sasser, 1990). Strain MJ27 $7^{\mathrm{T}}$ contained major amounts of $\mathrm{C}_{16: 0}(28.6 \%), \mathrm{C}_{16: 1} \omega 7 c(27.5 \%)$, $\mathrm{C}_{15: 1} \omega 6 c(13.8 \%)$ and $\mathrm{C}_{15: 0}(12.6 \%)$, a moderate amount of $\mathrm{C}_{17: 0}(5.6 \%)$ and minor amounts of iso- $\mathrm{C}_{16: 0}(2.6 \%)$, $\mathrm{C}_{16: 1} \omega 5 c(1.8 \%), \mathrm{C}_{14: 0}(1.7 \%)$, iso- $\mathrm{C}_{17: 0}(1.5 \%)$ and $\mathrm{C}_{15: 0}$ $(1.2 \%)$. The major fatty acids of strain MJ $27^{\mathrm{T}}$ are common to most recognized Deinococcus species (see Table 2), but there were some quantitative and qualitative differences between strain $\mathrm{MJ} 27^{\mathrm{T}}$ and the reference type strains.

To determine the polar lipid profile of strain $\mathrm{MJ} 27^{\mathrm{T}}$, total cellular polar lipids were extracted and examined by twodimensional TLC (Minnikin et al., 1977). Total lipids were observed after staining with $5 \%$ ethanolic molybdophosphoric acid and spots were detected by using $0.2 \%$ ninhydrin reagent (for aminolipids), $\alpha$-naphthol reagent (for glycolipids) and Zinzadze reagent (for phospholipids). Strain $\mathrm{MJ} 27^{\mathrm{T}}$ contained various unknown phosphoglycolipids $\left(\mathrm{PGL}_{1-2}\right)$, unknown glycolipids $\left(\mathrm{GL}_{1-7}\right)$ and unknown polar lipids (Fig. S1, available in IJSEM Online). The predominant polar lipid was unknown phosphoglycolipid $\mathrm{PGL}_{2}$, which is common to members of the genus Deinococcus (Ferreira et al., 1997; Weon et al., 2007; Im et al., 2008).

Table 2. Fatty acid profiles (\%) of strain $M J 27^{\top}$ and the type strains of closely related Deinococcus species

Strains: $1, \mathrm{MJ} 27^{\mathrm{T}}$; 2, D. aquaticus KCTC $12552^{\mathrm{T}}$; 3, D. caeni KCTC $12553^{\mathrm{T}}$; 4, D. grandis KACC $11979^{\mathrm{T}}$; 5, D. radiodurans KACC $12248^{\mathrm{T}}$. All strains were incubated on TSA for 2 days at $30{ }^{\circ} \mathrm{C}$. For unsaturated fatty acids, the position of the double bond is located by counting from the methyl $(\omega)$ end of the carbon chain. The cis isomers are indicated by the suffix $c$. Fatty acids amounting to $<1 \%$ of the total fatty acids in all strains are not shown. $\operatorname{Tr}$, trace $(<1 \%)$; ND, not detected.

\begin{tabular}{|c|c|c|c|c|c|}
\hline Fatty acid & 1 & 2 & 3 & 4 & 5 \\
\hline \multicolumn{6}{|l|}{ Saturated } \\
\hline $\mathrm{C}_{14: 0}$ & 1.7 & 3.4 & 2.4 & ND & ND \\
\hline iso- $\mathrm{C}_{14: 0}$ & $\operatorname{Tr}$ & $\operatorname{Tr}$ & $\mathrm{ND}$ & ND & ND \\
\hline $\mathrm{C}_{15: 0}$ & 12.6 & 8.4 & ND & 15.6 & 3.9 \\
\hline iso- $\mathrm{C}_{15: 0}$ & 1.2 & 2.3 & ND & 6.8 & ND \\
\hline$C_{16: 0}$ & 28.6 & 32.9 & 37.8 & 7.5 & 16.8 \\
\hline iso- $\mathrm{C}_{16: 0}$ & 2.6 & 1.2 & 2.8 & 4.8 & ND \\
\hline $\mathrm{C}_{17: 0}$ & 5.6 & 3.8 & 1.8 & 8.3 & 8.4 \\
\hline iso- $\mathrm{C}_{17: 0}$ & 1.5 & 6.8 & $\operatorname{Tr}$ & 2.3 & $\operatorname{Tr}$ \\
\hline anteiso- $\mathrm{C}_{17: 0}$ & $\mathrm{ND}$ & ND & ND & 8.6 & ND \\
\hline \multicolumn{6}{|l|}{ Unsaturated } \\
\hline $\mathrm{C}_{15: 1} \omega 6 c$ & 13.8 & ND & 2.4 & 28.6 & 7.8 \\
\hline $\mathrm{C}_{16: 1} \omega 5 c$ & 1.8 & $\operatorname{Tr}$ & 2.9 & 2.8 & 6.8 \\
\hline $\mathrm{C}_{16: 1} \omega 7 c$ & 27.5 & 38.5 & 48.9 & 13.8 & 42.8 \\
\hline $\mathrm{C}_{16: 1} \omega 9 c$ & $\mathrm{ND}$ & ND & ND & ND & 4.8 \\
\hline $\mathrm{C}_{18: 1} \omega 7 c$ & $\mathrm{ND}$ & ND & ND & ND & 4.3 \\
\hline $\mathrm{C}_{18: 1} \omega 9 c$ & $\mathrm{ND}$ & ND & ND & ND & 2.8 \\
\hline
\end{tabular}


For determination of the DNA $\mathrm{G}+\mathrm{C}$ content, genomic DNA was extracted as described above and enzymically degraded into nucleosides. The nucleosides were analysed by HPLC (Tamaoka \& Komagata, 1984; Mesbah et al., 1989). The DNA G+C content of strain $M J 27^{\mathrm{T}}$ was $67.6 \mathrm{~mol} \%$.

DNA-DNA hybridization was performed fluorometrically, according to the method developed by Ezaki et al. (1989), by using photobiotin-labelled DNA probes and microdilution wells. Hybridization was carried out reciprocally with five replications per sample. The highest and lowest values obtained for each sample were excluded; the remaining three values were utilized in the calculation of levels of relatedness, and values are quoted as means $( \pm \mathrm{SD})$ of these three values. Strain MJ27 ${ }^{\mathrm{T}}$ exhibited relatively low levels of DNA-DNA relatedness with D. aquaticus KCTC $12552^{\mathrm{T}}(5.3 \pm 1.5 \%)$, D. caeni KCTC $12553^{\mathrm{T}}(19.2 \pm 2.8 \%)$ and $D$. grandis KACC $11979^{\mathrm{T}}(29.2 \pm 2.3 \%)$. These values indicated that strain $\mathrm{MJ} 27^{\mathrm{T}}$ is not related to members of the genus Deinococcus at the species level (Wayne et al., 1987).

Data from the present polyphasic study clearly showed that strain $\mathrm{MJ} 27^{\mathrm{T}}$ represents a novel species of the genus Deinococcus, for which the name Deinococcus daejeonensis sp. nov. is proposed.

\section{Description of Deinococcus daejeonensis sp. nov.}

Deinococcus daejeonensis (da.e.je.on.en'sis. N.L. masc. adj. daejeonensis of or pertaining to Daejeon, a city in South Korea, from where the type strain was isolated).

Cells are Gram-stain-positive, strictly aerobic, non-motile, non-spore-forming cocci. After 3 days of incubation at $30{ }^{\circ} \mathrm{C}$ on $\mathrm{R} 2 \mathrm{~A}$ agar, colonies are $0.5-0.7 \mathrm{~mm}$ in diameter, red, smooth, convex and circular with regular edges. Good growth occurs at $15-37{ }^{\circ} \mathrm{C}$ (optimum, $30{ }^{\circ} \mathrm{C}$; weak growth at $40{ }^{\circ} \mathrm{C}$ ). Growth occurs at $\mathrm{pH} 6.0-8.5$ (optimum, $\mathrm{pH} 7.0$ 7.5). Growth occurs with $0-4 \%(\mathrm{w} / \mathrm{v}) \mathrm{NaCl}$, but not with $5 \% \mathrm{NaCl}$. Growth occurs on TSA, LB agar, NA and R2A agar. Positive for catalase and negative for oxidase. Nitrate is not reduced. Cells are highly resistant to gamma radiation $\left[D_{10}\right.$ (dose required to reduce the bacterial population by tenfold) $>9 \mathrm{kGy}$. In API ZYM and API 20NE strips, positive for acid phosphatase, alkaline phosphatase, arginine dihydrolase, $\alpha$-chymotrypsin, esterase, esterase lipase, $\beta$ galactosidase, gelatinase, $\alpha$-glucosidase, $\beta$-glucosidase, leucine arylamidase, naphthol-AS-BI-phosphohydrolase and valine arylamidase activities. Negative for $N$-acetyl- $\beta$-glucosaminidase, cystine arylamidase, $\alpha$-fucosidase, $\alpha$-galactosidase, $\beta$ glucuronidase, lipase, $\alpha$-mannosidase, trypsin and urease activities. In API ID 32 GN strips, assimilates D-glucose, 4-hydroxybenzoic acid, DL-lactate, D-mannitol, melibiose, myo-inositol, potassium 5-ketogluconate, L-rhamnose, salicin and sucrose, weakly assimilates L-alanine, caprate, citrate and 3-hydroxybenzoic acid, but does not assimilate $\mathrm{N}$ acetylglucosamine, adipate, L-arabinose, L-fucose, gluconate, glycogen, L-histidine, 3-hydroxybutyric acid, itaconate, 2ketogluconate, L-malate, D-maltose, malonate, D-mannose, L-proline, phenylacetate, propionate, D-ribose, L-serine, sodium acetate, $\mathrm{D}$-sorbitol, suberate or $\mathrm{n}$-valerate. The predominant respiratory quinone is MK-8. The major fatty acids $(>12 \%)$ are $\mathrm{C}_{16: 1} \omega 7 c, \mathrm{C}_{15: 1} \omega 6 c, \mathrm{C}_{16: 0}$ and $\mathrm{C}_{15: 0}$. The polar lipid profile is complex, containing various unknown phosphoglycolipids (including one major phosphoglycolipid), glycolipids and phospholipids. Ornithine and glycine are present in the peptidoglycan. The cell wall contains rhamnose and ribose.

The type strain, MJ27 $7^{\mathrm{T}}\left(=\mathrm{KCTC} 13751^{\mathrm{T}}=\mathrm{JCM} 16918^{\mathrm{T}}\right)$, was isolated from sludge at the Daejeon sewage disposal plant in South Korea. The genomic DNA G + C content of the type strain is $67.6 \mathrm{~mol} \%$.

\section{Acknowledgements}

This work was supported by the Eco-Technopia 21 project of the Ministry of Environment of the Republic of Korea (071-081-133).

\section{References}

Buck, J. D. (1982). Nonstaining ( $\mathrm{KOH})$ method for determination of Gram reactions of marine bacteria. Appl Environ Microbiol 44, 992993.

Brooks, B. W. \& Murray, R. G. E. (1981). Nomenclature for "Micrococcus radiodurans" and other radiation-resistant cocci: Deinococcaceae fam. nov. and Deinococcus gen. nov., including five species. Int J Syst Bacteriol 31, 353-360.

Cappuccino, J. G. \& Sherman, N. (2002). Microbiology: a Laboratory Manual, 6th edn. San Francisco: Benjamin Cummings.

Ezaki, T., Hashimoto, Y. \& Yabuuchi, E. (1989). Fluorometric deoxyribonucleic acid-deoxyribonucleic acid hybridization in microdilution wells as an alternative to membrane filter hybridization in which radioisotopes are used to determine genetic relatedness among bacterial strains. Int J Syst Bacteriol 39, 224-229.

Felsenstein, J. (1985). Confidence limits on phylogenies: an approach using the bootstrap. Evolution 39, 783-791.

Ferreira, A. C., Nobre, M. F., Rainey, F. A., Silva, M. T., Wait, R., Burghardt, J., Chung, A. P. \& da Costa, M. S. (1997). Deinococcus geothermalis sp. nov. and Deinococcus murrayi sp. nov., two extremely radiation-resistant and slightly thermophilic species from hot springs. Int J Syst Bacteriol 47, 939-947.

Fitch, W. M. (1971). Toward defining the course of evolution: minimum change for a specific tree topology. Syst Zool 20, 406-416.

Hall, T. A. (1999). BioEdit: a user-friendly biological sequence alignment editor and analysis program for Windows 95/98/NT. Nucleic Acids Symp Ser 41, 95-98.

Hiraishi, A., Ueda, Y., Ishihara, J. \& Mori, T. (1996). Comparative lipoquinone analysis of influent sewage and activated sludge by highperformance liquid chromatography and photodiode array detection. J Gen Appl Microbiol 42, 457-469.

Im, W. T., Jung, H. M., Ten, L. N., Kim, M. K., Bora, N., Goodfellow, M., Lim, S., Jung, J. \& Lee, S. T. (2008). Deinococcus aquaticus sp. nov., isolated from fresh water, and Deinococcus caeni sp. nov., isolated from activated sludge. Int J Syst Evol Microbiol 58, 2348-2353.

Kim, M. K., Im, W.-T., Ohta, H., Lee, M. \& Lee, S.-T. (2005). Sphingopyxis granuli sp. nov., a $\beta$-glucosidase-producing bacterium 
in the family Sphingomonadaceae in $\alpha-4$ subclass of the Proteobacteria. J Microbiol 43, 152-157.

Kimura, M. (1983). The Neutral Theory of Molecular Evolution. Cambridge: Cambridge University Press.

Kumar, S., Tamura, K. \& Nei, M. (2004). MEGA3: integrated software for molecular evolutionary genetics analysis and sequence alignment. Brief Bioinform 5, 150-163.

Kuykendall, L. D., Roy, M. A., O'Neill, J. J. \& Devine, T. E. (1988). Fatty acids, antibiotic resistance and deoxyribonucleic acid homology groups of Bradyrhizobium japonicum. Int J Syst Bacteriol 38, 358-361.

Kwon, J. Y. \& Seo, Y. R. (2010). Genome-wide profiling induced by ionizing radiation (IR) in non-small cell lung cancer (NSCLC) grown as three-dimensional spheroid. Mol Cell Toxicol 6, 229-237.

Mesbah, M., Premachandran, U. \& Whitman, W. B. (1989). Precise measurement of the $\mathrm{G}+\mathrm{C}$ content of deoxyribonucleic acid by highperformance liquid chromatography. Int J Syst Bacteriol 39, 159-167.

Minnikin, D. E., Patel, P. V., Alshamaony, L. \& Goodfellow, M. (1977). Polar lipid composition in the classification of Nocardia and related bacteria. Int J Syst Bacteriol 27, 104-117.

Oyaizu, H., Stackebrandt, E., Schleifer, K. H., Ludwig, W., Pohla, H., Ito, H., Hirata, A., Oyaizu, Y. \& Komagata, K. (1987). A radiationresistant rod-shaped bacterium, Deinobacter grandis gen. nov., sp. nov., with peptidoglycan containing ornithine. Int J Syst Bacteriol 37, 62-67.

Rainey, F. A., Ray, K., Ferreira, M., Gatz, B. Z., Nobre, M. F., Bagaley, D., Rash, B. A., Park, M. J., Earl, A. M. \& other authors (2005). Extensive diversity of ionizing-radiation-resistant bacteria recovered from Sonoran Desert soil and description of nine new species of the genus Deinococcus obtained from a single soil sample. Appl Environ Microbiol 71, 5225-5235.

Saitou, N. \& Nei, M. (1987). The neighbor-joining method: a new method for reconstructing phylogenetic trees. Mol Biol Evol 4, 406425.

Sasser, M. (1990). Identification of bacteria by gas chromatography of cellular fatty acids, MIDI Technical Note 101. Newark, DE: MIDI Inc.

Schleifer, K. H. \& Kandler, O. (1972). Peptidoglycan types of bacterial cell walls and their taxonomic implications. Bacteriol Rev 36, 407-477.

Seong, K. M., Kim, C. S., Jeon, H. Y., Oh, S.-H., Nam, S. Y., Yang, K. H., Kim, J.-Y. \& Jin, Y.-W. (2010). Intrinsic radiosensitivity correlated with radiation-induced ROS and cell cycle regulation. Mol Cell Toxicol 6, 1-7.

Tamaoka, J. \& Komagata, K. (1984). Determination of DNA base composition by reversed-phase high-performance liquid chromatography. FEMS Microbiol Lett 25, 125-128.

Thompson, J. D., Gibson, T. J., Plewniak, F., Jeanmougin, F. \& Higgins, D. G. (1997). The CLUSTAL_X windows interface: flexible strategies for multiple sequence alignment aided by quality analysis tools. Nucleic Acids Res 25, 4876-4882.

Wayne, L. G., Brenner, D. J., Colwell, R. R., Grimont, P. A. D., Kandler, O., Krichevsky, M. I., Moore, L. H., Moore, W. E. C., Murray, R. G. E. \& other authors (1987). International Committee on Systematic Bacteriology. Report of the ad hoc committee on reconciliation of approaches to bacterial systematics. Int J Syst Bacteriol 37, 463-464.

Weon, H. Y., Kim, B. Y., Schumann, P., Son, J. A., Jang, J., Go, S. J. \& Kwon, S. W. (2007). Deinococcus cellulosilyticus sp. nov., isolated from air. Int J Syst Evol Microbiol 57, 1685-1688. 